\title{
Effects of plant food potassium salts (citrate, galacturonate or tartrate) on acid-base status and digestive fermentations in rats
}

\author{
Houda Sabboh, Véronique Coxam, Marie-Noëlle Horcajada, Christian Rémésy and Christian Demigné* \\ INRA, UMR 1019, Unité Nutrition Humaine, Centre de Clermont-Ferrand-Theix, F-63122, France \\ (Received 11 September 2006 - Revised 4 January 2007 - Accepted 10 January 2007)
}

\begin{abstract}
Potassium (K) organic anion salts, such as potassium citrate or potassium malate in plant foods, may counteract low-grade metabolic acidosis induced by western diets, but little is known about the effect of other minor plant anions. Effects of $\mathrm{K}$ salts (chloride, citrate, galacturonate or tartrate) were thus studied on the mineral balance and digestive fermentations in groups of 6-week-old rats adapted to an acidogenic/5\% inulin diet. In all diet groups, substantial amounts of lactate and succinate were present in the caecum, besides SCFA. SCFA were poorly affected by $\mathrm{K}$ salts conditions. The KCl-supplemented diet elicited an accumulation of lactate in the caecum; whereas the lactate caecal pool was low in rats fed the potassium tartrate-supplemented (K TAR) diet. A fraction of tartrate (around 50\%) was recovered in urine of rats fed the K TAR diet. Potassium citrate and potassium galacturonate diets exerted a marked alkalinizing effect on urine $\mathrm{pH}$ and promoted a notable citraturia (around $0.5 \mu \mathrm{mol} / 24 \mathrm{~h}$ ). All the $\mathrm{K}$ organic anion salts counteracted $\mathrm{Ca}$ and $\mathrm{Mg}$ hyperexcretion in urine, especially potassium tartrate as to magnesuria. The present findings indicate that $\mathrm{K}$ salts of unabsorbed organic anions exert alkalinizing effects when metabolizable in the large intestine, even if K and finally available anions (likely SCFA) are not simultaneously bioavailable. Whether this observation is also relevant for a fraction of SCFA arising from dietary fibre breakdown (which represents the major organic anions absorbed in the digestive tract in man) deserves further investigation.
\end{abstract}

Potassium: Organic anions: Fermentation: Acid-base balance: Calcium: Magnesium

Health effects of fruits and vegetables are increasingly taken into account in the prevention of chronic diseases such as CVD or diabetes (Lock et al. 2005), these effects being largely ascribed to the presence of non-energetic nutriments such as fibres, polyphenols, vitamins and minerals. In this view, fruits and vegetables are practically the unique source of $K$ organic salts (predominantly potassium malate and potassium citrate) liable to exert alkalinizing effects after metabolization, with a potential to prevent low-grade metabolic acidosis inherent to westernized diet habits (Frassetto et al. 1998; Remer, 2000) hence some chronic pathologies such as osteopenia/osteoporosis or sarcopenia (Young \& Ma, 1999; Demigné et al. 2004b). Plant foods also contain some other organic anions (oxalate, succinate, tartrate, galacturonate) which display different absorption and metabolism characteristics. For example, D-galacturonate is a major component of plant cell wall polysaccharides such as pectins, and free galacturonate is found in small amounts in fruits and vegetables and it also originates from pectin breakdown by the colonic microflora (Dongowski et al. 2002). In contrast to malate or citrate, the galacturonate anion is poorly absorbed in the small intestine (Pajor, 1999) but is well metabolized by the large intestine microflora (Mortensen et al. 1988; Aprikian et al.
2003). Tartrate is essentially found, in its natural $\mathrm{L}(+)$ form, in grapes. Some tartrate ions bypass the small intestine and are fermented by colonic bacteria, which utilize the ions for the production of SCFA, just as dietary fibre is used (Spiller et al. 2003). It has also been shown that around $30 \%$ of ingested tartrate appears unchanged in the urine (Chadwick et al. 1978), reflecting some absorption in the small intestine.

The amounts of organic anions generated by microbial fermentations of unavailable carbohydrates in the large intestine, predominantly SCFA (namely acetate, propionate and butyrate), may be 5-10-fold greater than the amounts of ingested organic anions (Demigné et al. 2004a). Their alkalinizing potential is still a matter of discussion since they are not systematically absorbed in parallel with cations: they may be absorbed as protonated forms or in exchange with bicarbonate, as well as anionic species through a paracellular route (Sellin, 1999; Vidyasagar et al. 2004).

To further investigate the actual impact of various $\mathrm{K}$ salts on low-grade metabolic acidosis and on digestive fermentations, Wistar rats were adapted to an acidogenic diet (relatively high in protein and sodium, and poor in $\mathrm{K}$ and alkalinizing anions) which was supplemented with different $\mathrm{K}$ salts, of inorganic or organic anions.

\footnotetext{
Abbreviations: K CIT diet, potassium citrate-supplemented diet; K GAL diet, potassium galacturonate-supplemented diet; K TAR diet, potassium tartratesupplemented diet; $\mathrm{KCl}$ diet, $\mathrm{KCl}$-supplemented diet.

* Corresponding author: Dr Christian Demigné, fax +334736246 38, email demigne@clermont.inra.fr
} 


\section{Materials and methods}

\section{Experimental diets}

Five experimental diets were used: control, KCl-supplemented $(\mathrm{KCl})$, potassium citrate-supplemented (K CIT), potassium galacturonate-supplemented (K GAL) or potassium tartratesupplemented (K TAR). All the diets contained (in $\mathrm{g} / \mathrm{kg}$ ): casein 200 (Louis François CIE, Saint-Maur, France), methionine 3, fat 100 (maize oil), sucrose 100 , inulin $50, \mathrm{NaCl}$ 15, $\mathrm{CaH}\left(\mathrm{PO}_{4}\right) \cdot 2\left(\mathrm{H}_{2} \mathrm{O}\right) \quad 12 \cdot 8, \mathrm{MgO} 0 \cdot 8, \mathrm{KCl} 4.8$ (all from Sigma, St Louis, MO, USA), together with trace element mix 10 and vitamin mix 10 each (AIN-93; Dyets Inc., Bethlehem, PA, USA) and wheat starch quantum satis for $1000 \mathrm{~g}$ (around $470 \mathrm{~g} / \mathrm{kg}$ ). High $\mathrm{K}$ diets were also prepared on the same basis as the control diet, by adding either $\mathrm{KCl}(29 \mathrm{~g} /$ $\mathrm{kg})$ or $\mathrm{K}(\mathrm{D})$ galacturonate $(42.5 \mathrm{~g} / \mathrm{kg})$ or $\mathrm{K}_{3}$ citrate $(42.1 \mathrm{~g} / \mathrm{kg})$ or $\mathrm{K}_{2}$ tartrate $(47.9 \mathrm{~g} / \mathrm{kg})$, at the expense of wheat starch. Dietary $\mathrm{K}$ concentration was either $2.5 \mathrm{~g} / \mathrm{kg}$ (low $\mathrm{K}$ diet) or $15.2 \mathrm{~g}$ / $\mathrm{kg}$ (high $\mathrm{K}$ diets). The final concentrations of $\mathrm{Na}, \mathrm{Ca}$ and $\mathrm{Mg}$ in all diets were $5.9,3.0$ and $0.5 \mathrm{~g} / \mathrm{kg}$, respectively, and the overall sulphur amino acid content of the diet was around $10 \mathrm{~g} / \mathrm{kg}$.

\section{Animals and sampling procedures}

Rats were maintained and handled according to the recommendations of the INRA Ethics Committee, in accordance with decree no. 87-848. Male Wistar rats (IFFA/CREDO, L'Arbresle, France) weighing approximately $180 \mathrm{~g}$ (6 weeks old) were randomly allocated to five groups of eight rats and were fed, for $21 \mathrm{~d}$, one of the semi-purified diets distributed as a moistened powder. The rats were housed in Nalgene metabolic cages (UAR, Villemoisson, Epinay/Orge, France) with a feeder chamber outside the cage, minimizing food spillage. The separator device allows faecal pellets to roll downside of a stainless steel funnel (itself directing urine to a collector vessel) to be collected in tubes. Animals were maintained in temperature-controlled conditions $\left(22^{\circ} \mathrm{C}\right)$ with a dark period from 20.00 to 08.00 hours and access to food during the dark period and free access to water (distilled water). Body weight was recorded on days $0,7,14$ and 21 of the experiment; food intake determination and collection of urine were performed on 4 consecutive days at the end of the experiment.
At the time of sampling (09.00 hours), rats were anaesthetized with sodium pentobarbital $(40 \mathrm{mg} / \mathrm{kg}$ body weight) and maintained on a plate at $37^{\circ} \mathrm{C}$. Blood was drawn from the abdominal aorta into a heparinized syringe and plasma was obtained after centrifugation at $10000 \mathrm{~g}$ for $2 \mathrm{~min}$. The caecum was removed, weighed and the contents were collected in microfuge tubes. Plasma, urine and caecal contents were stored at $-20^{\circ} \mathrm{C}$ until analysis. Therafter, rats were killed by an overdose of pentobarbital.

\section{Analytical procedures}

Faecal materials were submitted to dry-ashing $\left(10 \mathrm{~h}\right.$ at $\left.500^{\circ} \mathrm{C}\right)$. The resulting ash was redissolved in $\mathrm{HCl}(6 \mathrm{~mol} / \mathrm{l})$ and made up to an appropriate volume with lanthanum solution $(1 \mathrm{~g} / \mathrm{l})$. $\mathrm{K}^{+}, \mathrm{Ca}^{2+}$ and $\mathrm{Mg}^{2+}$ in plasma, urine and stools were quantified using a PE560 atomic absorption spectrometer (Perkin Elmer, St-Quentin-en-Yvelines, France).

For analysis of anions, except SCFA, biological samples were diluted with milli-Q water (caecal supernatants 200fold and urine 400-fold) and analysed using a DX320 Dionex chromatograph (Dionex, Sunnyvale, CA, USA). Caecal supernatants were obtained by centrifugation of caecal content samples at $40000 \mathrm{~g}$ for $15 \mathrm{~min}$. SCFA (acetate, propionate and butyrate) were measured by GLC on caecal supernatants (Demigné \& Rémésy, 1985).

\section{Statistical analysis}

Values are given as means and their standard errors and significance of differences $(P<0.05)$ between mean values was determined by ANOVA coupled with the Student's Newman-Keuls test.

\section{Results}

As shown in Table 1, the daily food intake and weight gain were not significantly different between the experimental groups, and compared to controls. The urine volume was significantly higher in rats adapted to the K GAL or K TAR diets, compared to rats adapted to the control diet. Urine $\mathrm{pH}$ in rats fed the acidogenic control diet was low (pH 5.84) as expected, whereas the urine $\mathrm{pH}$ was alkaline in rats adapted to the K CIT and K GAL diets ( $\mathrm{pH} 7.80$ and 7.55 , respectively). Rats fed the K TAR diet excreted urine practically as acidic as the

Table 1. Daily food intake, weight gain, and caecal and urinary parameters in rats adapted to acidogenic diets containing $5 \%$ inulin, which were supplemented with different potassium salts (providing $15 \mathrm{~g}$ potassium/ $\mathrm{kg}$ diet)

(Mean values with their standard errors for eight animals in each experimental group)

\begin{tabular}{|c|c|c|c|c|c|c|c|c|c|c|c|}
\hline & \multicolumn{2}{|c|}{ Control diet } & \multicolumn{2}{|c|}{$\begin{array}{l}\text { Potassium } \\
\text { chloride diet }\end{array}$} & \multicolumn{2}{|c|}{$\begin{array}{l}\text { Potassium } \\
\text { citrate diet }\end{array}$} & \multicolumn{2}{|c|}{$\begin{array}{c}\text { Potassium } \\
\text { galacturonate diet }\end{array}$} & \multicolumn{2}{|c|}{$\begin{array}{l}\text { Potassium } \\
\text { tartrate diet }\end{array}$} & \multirow[b]{2}{*}{$P$} \\
\hline & Mean & SEM & Mean & SEM & Mean & SEM & Mean & SEM & Mean & SEM & \\
\hline Food intake (g/d) & 17.65 & 0.62 & $18 \cdot 22$ & 0.80 & $17 \cdot 44$ & 0.91 & $18 \cdot 82$ & 0.72 & $17 \cdot 31$ & 0.79 & NS \\
\hline Weight gain $(g / d)$ & 4.90 & 0.28 & $6 \cdot 10$ & 0.38 & 5.55 & 0.40 & $5 \cdot 33$ & 0.27 & $5 \cdot 33$ & 0.39 & NS \\
\hline Urine excretion $(\mathrm{ml} / \mathrm{d})$ & $13 \cdot 83$ & 0.57 & $13 \cdot 58$ & 1.55 & $14 \cdot 67$ & 1.48 & $18 \cdot 92$ & 1.64 & $17 \cdot 58$ & $2 \cdot 39$ & NS \\
\hline Urine $\mathrm{pH}$ & $5 \cdot 84^{a}$ & 0.27 & $5.55^{\mathrm{b}}$ & 0.02 & $7 \cdot 80^{c}$ & 0.18 & $7 \cdot 55^{c}$ & 0.14 & $6 \cdot 08^{a}$ & 0.10 & $<0.001$ \\
\hline Caecum total weight $(\mathrm{g})$ & 4.85 & 1.59 & $6 \cdot 74$ & 0.62 & $4 \cdot 39$ & 0.53 & 5.53 & 0.86 & $6 \cdot 23$ & 0.77 & NS \\
\hline Caecum $\mathrm{pH}$ & $5 \cdot 78^{\mathrm{a}}$ & 0.23 & $5 \cdot 11^{b}$ & 0.08 & $5 \cdot 68^{\mathrm{a}}$ & 0.21 & $5 \cdot 30^{\mathrm{ab}}$ & 0.11 & $5 \cdot 17^{\mathrm{b}}$ & 0.15 & $<0.02$ \\
\hline
\end{tabular}

${ }^{a, b, c}$ Mean values within a row with unlike superscript letters were significantly different $(P<0.05)$. 
controls and rats fed the $\mathrm{KCl}$ diet excreted a particularly acidic urine ( $\mathrm{pH}$ 5.55).

Due to the presence of $5 \%$ inulin in the diet, the caecal weight was relatively high (around $5.5 \mathrm{~g}$ ) compared to fibrefree conditions (data not presented), and there was no significant difference between the caecal weight of the diet groups. The luminal $\mathrm{pH}$ in the caecum was moderately acidic in control rats ( $\mathrm{pH} 5.78)$, it was more acidic in rats fed the $\mathrm{K}$ GAL or $\mathrm{K}$ TAR diets, and especially in rats fed the $\mathrm{KCl}$ diet ( $\mathrm{pH} 5 \cdot 11$ ).

Table 2 shows that the control diet resulted in a caecal fermentation profile moderately rich in SCFA, together with substantial amounts of lactate and succinate anions. The acidic $\mathrm{pH}$ conditions in the caecum of rats fed the $\mathrm{KCl}$ or $\mathrm{K}$ TAR diets was accompanied by a marked accumulation of succinate, together with large amounts of lactate anions and limited quantities of SCFA in rats fed the $\mathrm{KCl}$ diet. In contrast, relatively high amounts of SCFA and moderate amounts of lactate were observed in the caecum of the K TAR group. Compared to controls, there were few changes in the caecal organic anions in the K CIT group, except a significant drop in succinate, but there was a rise in total SCFA in the K GAL group. It must be noted that detectable concentrations of galacturonate ( $7.6 \mathrm{mmol} / \mathrm{g}$ content) were found in the caecum of rats fed the K GAL diet, as well as of tartrate $(4.7 \mathrm{mmol} / \mathrm{g}$ content) in rats fed the K TAR group, whereas citrate was almost undetectable in the KCIT diet group.

Table 3 presents the effect of the diets on urine excretion of anions. As expected, chloride excretion was particularly high in rats fed the $\mathrm{KCl}$ group. Phosphate excretion was higher in rats fed the K TAR diet than in the other diet group, whilst sulphate excretion was maximal in rats adapted to the alkalinizing K CIT and K GAL diets. In these K CIT and K GAL diet groups, a substantial citraturia was measured, whereas only trace amounts of citrate could be detected in the urine of rats fed the K TAR diet; these rats exhibited a substantial elimination of tartrate ions by kidneys $(2.2 \mathrm{mmol} / 24 \mathrm{~h}$, hence about $50 \%$ of tartrate intake).

As shown in Fig. 1, there was a consistent calciuria and magnesuria in rats adapted to the control or $\mathrm{KCl}$ acidogenic diets. Ca excretion was lower in rats adapted to the K CIT, $\mathrm{K}$ GAL and K TAR diets $(8.7,11.9$ and $5.8 \mu \mathrm{mol} / 24 \mathrm{~h}$, respectively), compared to control rats (around $100 \mu \mathrm{mol} /$ $24 \mathrm{~h}$ ). The same effect, although less drastic, was observed for $\mathrm{Mg}$ excretion with a noticeable impact of the $\mathrm{K}$ TAR $\operatorname{diet}(8.74 \mu \mathrm{mol} / 24 \mathrm{~h} v .20 \mu \mathrm{mol} / 24 \mathrm{~h}$ for the control).

\section{Discussion}

\section{Digestive fermentations and dietary anions}

Investigations on the possible interactions between fibres and minerals are still scarce and essentially focused on the effects of fructans on $\mathrm{Ca}$ or $\mathrm{Mg}$ absorption or on the effects of SCFA on distal Na recovery (Rechkemmer et al. 1988; Kunzelmann \& Mall, 2003). In the present study, the caecal anion profile was characterized by a relatively high concentration of succinate in all the diet groups, likely due to the presence of inulin in the diet which promotes acidic fermentations (Rémésy et al. 1993). Succinate, an intermediate in the fermentation process of microbiota, is generally metabolized to SCFA (as a major precursor of propionate) by cross-feeding species in the ecosystem and it does not usually accumulate to a substantial extent in the bowel (Bernalier et al. 1999). Nevertheless, some data suggest that sizeable amounts of succinate may be detected in the large intestine when adequate techniques are used (Morita et al. 1998; Aprikian et al. 2003). It is noteworthy that the $\mathrm{KCl}$ diet led to an acidification of the caecal content although this diet would not provide additional fermentable substrate. $\mathrm{Cl}^{-}$concentrations were not enhanced in the caecal lumen or the ileum (data not shown), but the organic anion profile measured with this diet (high lactate/low SCFA) is characteristic of highly acidic fermentations (Rémésy et al. 1993). The K CIT diet showed limited effects on caecal fermentations, whereas the K GAL diet promoted high SCFA fermentations, in accordance with the fact that galacturonate is extensively metabolized in the caecum (Suzuki \& Kajuu, 1983; Mortensen et al. 1988). A substantial amount of the tartrate was not absorbed and reached the caecum, where it should be metabolized by the microflora (Finkle, 1933; Spiller et al. 2003). The effects of the K TAR diet were quite particular and not strictly consistent with the relatively acidic $\mathrm{pH}$ conditions observed in the caecum of rats adapted to this diet, since lactate was strongly depressed whilst large amounts of succinate were found. These differences between $K$ TAR and K GAL diets (both containing a fermentable anion), on the one hand, and between $\mathrm{K} \mathrm{TAR}$ and $\mathrm{KCl}$ diets (both acidifying), on the other hand, are still to be explained but indicate that anions such as tartrate are able to exert a specific influence on digestive fermentations.

Table 2. Caecal pools* of anions and SCFA in rats adapted to acidogenic diets containing $5 \%$ inulin, which were supplemented with different potassium salts (providing $15 \mathrm{~g}$ potassium $/ \mathrm{kg}$ diet)

(Mean values with their standard errors for eight animals in each experimental group)

\begin{tabular}{|c|c|c|c|c|c|c|c|c|c|c|c|}
\hline & \multicolumn{2}{|c|}{ Control diet } & \multicolumn{2}{|c|}{$\begin{array}{l}\text { Potassium } \\
\text { chloride diet }\end{array}$} & \multicolumn{2}{|c|}{$\begin{array}{l}\text { Potassium } \\
\text { citrate diet }\end{array}$} & \multicolumn{2}{|c|}{$\begin{array}{l}\text { Potassium } \\
\text { galacturonate diet }\end{array}$} & \multicolumn{2}{|c|}{$\begin{array}{l}\text { Potassium } \\
\text { tartrate diet }\end{array}$} & \multirow[b]{2}{*}{$P$} \\
\hline & Mean & SEM & Mean & SEM & Mean & SEM & Mean & SEM & Mean & SEM & \\
\hline Acetate & 102 & 23 & 53 & 20 & 127 & 14 & 191 & 18 & 169 & 16 & NS \\
\hline Propionate & 68 & 11 & 46 & 8 & 61 & 15 & 68 & 14 & 57 & 10 & NS \\
\hline Butyrate & $40^{\mathrm{a}}$ & 8 & $22^{b}$ & 5 & $52^{\mathrm{a}}$ & 13 & $70^{\mathrm{a}}$ & 15 & $27^{\mathrm{a}}$ & 3 & $<0.05$ \\
\hline Lactate & $108^{a}$ & 27 & $325^{\mathrm{b}}$ & 42 & $107^{\mathrm{a}}$ & 17 & $70^{\mathrm{a}}$ & 12 & $23^{\mathrm{C}}$ & 6 & $<0.05$ \\
\hline Succinate & 173 & 34 & 302 & 29 & 136 & 35 & 228 & 20 & 345 & 27 & NS \\
\hline
\end{tabular}

a,b,c Mean values within a row with unlike superscript letters were significantly different $(P<0.05)$.

${ }^{\star}$ Caecal pool (in $\left.\mu \mathrm{mol}\right)=$ caecal concentration (in $\left.\mu \mathrm{mol} / \mathrm{g}\right) \times$ caecal content weight (in $\left.\mathrm{g}\right)$. 
Table 3. Urine excretion ( $\mathrm{mmol} / 24 \mathrm{~h}$ ) of anions in rats adapted to acidogenic diets containing $5 \%$ inulin, which were supplemented with different potassium salts (providing $15 \mathrm{~g}$ potassium $/ \mathrm{kg}$ diet)

(Mean values with their standard errors for eight animals in each experimental group)

\begin{tabular}{|c|c|c|c|c|c|c|c|c|c|c|c|}
\hline & \multicolumn{2}{|c|}{ Control diet } & \multicolumn{2}{|c|}{$\begin{array}{l}\text { Potassium } \\
\text { chloride diet }\end{array}$} & \multicolumn{2}{|c|}{$\begin{array}{l}\text { Potassium } \\
\text { citrate diet }\end{array}$} & \multicolumn{2}{|c|}{$\begin{array}{c}\text { Potassium } \\
\text { galacturonate diet }\end{array}$} & \multicolumn{2}{|c|}{$\begin{array}{l}\text { Potassium } \\
\text { tartrate diet }\end{array}$} & \multirow[b]{2}{*}{$P$} \\
\hline & Mean & SEM & Mean & SEM & Mean & SEM & Mean & SEM & Mean & SEM & \\
\hline Chloride & $6 \cdot 41^{\mathrm{a}}$ & 0.40 & $12 \cdot 81^{b}$ & 1.01 & $4 \cdot 85^{a}$ & 0.44 & $6 \cdot 67^{\mathrm{a}}$ & 0.49 & $5 \cdot 72^{\mathrm{a}}$ & 0.80 & $<0.005$ \\
\hline Sulphate & $0.25^{\mathrm{a}}$ & 0.02 & $0.34^{a}$ & 0.05 & $0.67^{\mathrm{b}}$ & 0.07 & $0.56^{\mathrm{b}}$ & 0.07 & $0.39^{a b}$ & 0.07 & $<0.005$ \\
\hline Phosphate & $0.99^{a}$ & 0.07 & $1 \cdot 12^{\mathrm{a}}$ & 0.12 & $1.06^{a}$ & 0.09 & $1 \cdot 18^{a}$ & 0.11 & $1 \cdot 85^{\mathrm{b}}$ & 0.19 & $<0.001$ \\
\hline Citrate & 0 & & 0 & & $0.54^{a}$ & 0.05 & $0.43^{a}$ & 0.04 & $0.02^{b}$ & 0.02 & $<0.001$ \\
\hline Tartrate & 0 & & 0 & & 0 & & 0 & & 2.20 & 0.25 & \\
\hline
\end{tabular}

${ }^{a, b}$ Mean values within a row with unlike superscript letters were significantly different $(P<0.05)$.

\section{Alkalinizing potency of the different potassium salts}

The role of dietary $\mathrm{K}$ organic anion salts, such as potassium citrate or potassium malate, as neutralizing factors of the fixed acidity generated by protein catabolism in the body is now well recognized (He \& McGregor, 2001; Marangella et al. 2004). These anions are well absorbed and readily metabolized in various tissues (Demigné et al. 2004a). In the present study, with the K CIT diet there was a relative excess of citrate anion (around $25 \mathrm{~g} / \mathrm{kg}$ ) compared to that of sulphur amino acids (around $10 \mathrm{~g} / \mathrm{kg}$ ). In contrast, human western diets are generally characterized by an excess of sulphur
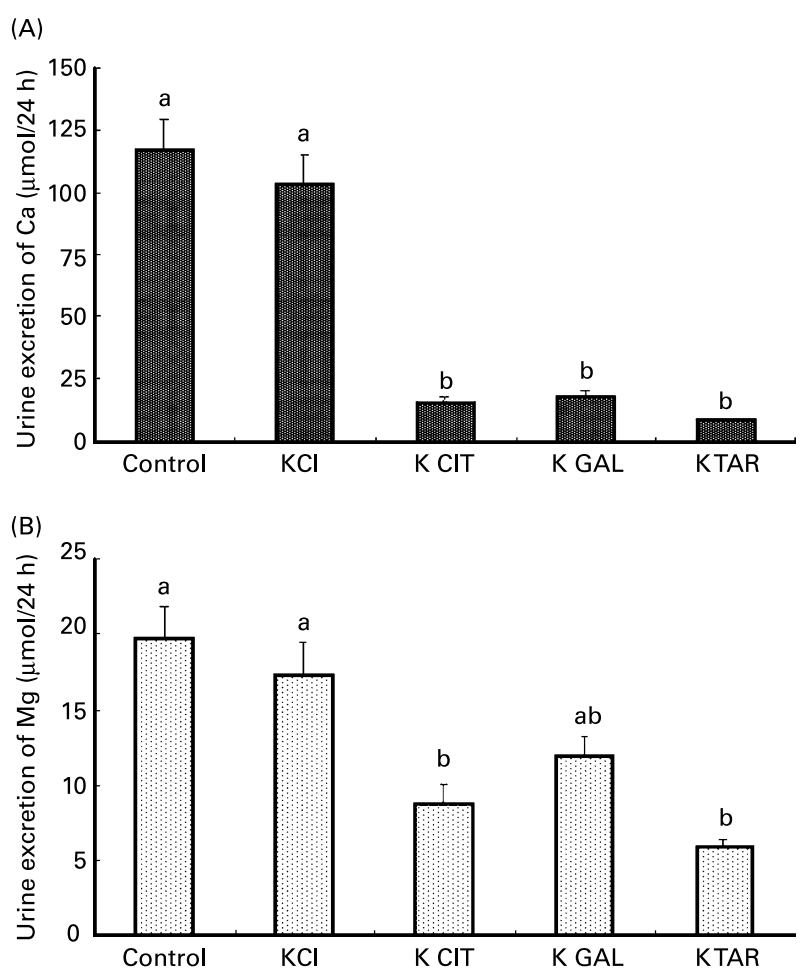

Fig. 1. Urine excretion of calcium $(A)$ and magnesium $(B)$ in rats adapted to acidogenic diets containing $5 \%$ inulin, which were supplemented with different potassium salts ( $\mathrm{K} \mathrm{CIT}$, potassium citrate; $\mathrm{K} \mathrm{GAL}$, potassium galacturonate; $\mathrm{K}$ TAR, potassium tartrate; providing $15 \mathrm{~g}$ potassium $/ \mathrm{kg}$ diet). Values are means with their standard errors depicted by vertical bars (eight animals in each experimental group). ${ }^{a, b}$ Mean values with unlike superscript letters were significantly different $(P<0.05)$. amino acids ( $3-4 \mathrm{~g} / \mathrm{d}$ ) compared to organic anions (frequently less that $1 \mathrm{~g} / \mathrm{d}$ ). In fact, in addition to citrate and malate, other secondary anions are also present in plant foods (oxalate, tartrate, uronic anions) but in lesser amounts. Besides, amounts of SCFA generated by microbial fermentations of carbohydrates in the large intestine are far greater than the amounts of ingested malate and citrate (Demigné et al. 2004a). Their alkalinizing potential is still a matter of discussion since (1) they are not systematically absorbed in parallel with cations and (2) they may be absorbed as protonated forms or as anionic species, in exchange with bicarbonate (Vidyasagar et al. 2004). Nevertheless, should a minor part of absorbed SCFA (e.g. $10 \%$ ) be absorbed together with cations and exert alkalinizing effects, it could substantially raise the overall alkalinizing potential of a given diet. To assess this possibility, a prerequisite was to determine whether substrates providing $\mathrm{K}^{+}$and yielding anions in the large intestine could be effective alkalinizing agents. The results obtained here with potassium galacturonate indeed support the view that a combination of [K/anions absorbed from the caecum] is practically as effective as an equivalent amount of potassium citrate. Galacturonate is poorly absorbed in the small intestine (undetectable in urine, present in high concentrations in ileal contents) and is metabolized in the caecum (Mortensen et al. 1988; Aprikian et al. 2003). Whether SCFA mediate this alkalinizing effect, or other organic anions also present in the caecum (lactate, succinate), is still to be ascertained but all these anions are realily metabolized in mammal tissues and finally yield $\mathrm{HCO}_{3}^{-}$ (Rémésy et al. 1995). During the course of digestion, $\mathrm{K}$ and galacturonate were probably absorbed at a different rate: $\mathrm{K}$ is very rapidly absorbed in the upper small intestine, whereas galacturonate has to reach the caecum before being metabolized by the microflora into absorbable anion(s). The major part of absorbed $\mathrm{K}$ is not immediately eliminated in urine since it is submitted to a transitory storage in tissues, especially muscles, from which it is progressively released for further renal elimination (McDonough et al. 2002). In contrast to potassium galacturonate, the potassium tartrate alkalinizing effects were quite limited, although about $50 \%$ of tartrate escapes absorption in the small intestine as previously reported (Chadwick et al. 1978) and reaches the large intestine (where its metabolism probably yields absorbable anions). This discrepancy with galacturonate could reflect the fact that absorbed tartrate is not metabolized and might contribute to fixed acidity in urine (Lord et al. 2005). However, this is in 
discrepancy with the notable anticalciuric and antimagnesuric effects presently observed with potassium tartrate, as potent as those of potassium citrate (Sabboh et al. 2005) or potassium galacturonate, in spite of a modest alkalinization of urine with potassium tartrate. This point deserves further investigations and suggests that some effects of $\mathrm{K}$ organic anion salts might not be entirely due to their alkalinizing potency but might depend on other mechanisms (specific role of $\mathrm{K}$, effects on phosphaturia).

It is noteworthy that the K CIT diet, and to a lesser extent the $\mathrm{K}$ GAL diet, slightly enhanced $\mathrm{SO}_{4}^{2-}$ excretion. Metabolic acidosis has been shown to reduce $\mathrm{SO}_{4}^{2-}$ reabsorption in kidneys (Puttaparthi et al. 1999) as well as chronic renal failure (Fernandes et al. 2001). On this basis, alkalinizing agents might restore $\mathrm{SO}_{4}^{2-}$ reabsorption through a reversal of transporter down-regulation by acidosis and possibly through provision of $\mathrm{HCO}_{3}^{-}$for the $\mathrm{SO}_{4}^{2-}$ /anion exchanger. As a matter of fact, the greater rate of $\mathrm{SO}_{4}^{2-}$ excretion in rats fed the alkalinizing diets suggests that its reabsorption, whether activated or not, could not match an increased generation of $\mathrm{SO}_{4}^{2-}$. Phosphate is the major buffer system in urine and its excretion is generally increased during acidosis, as a result of a decrease of the preferentially transported form $\left(\mathrm{HPO}_{4}^{2-}\right)$ together with a direct effect of $\mathrm{pH}$ on the apical phosphate carrier in the proximal tubule (Ambuhl et al. 1998). In the present experiment, this response to acidosis was not apparent, possibly a reflection of the high level of phosphate in the rat diets (also a feature of western diets).

\section{Conclusion}

The present study indicates that $\mathrm{K}$ salts of unabsorbed organic anions, if metabolizable in the large intestine, may exert effective alkalinizing effects even if $\mathrm{K}$ and finally available anions (likely SCFA) are not simultaneously bioavailable. This point is interesting because it implies that the alkalinizing effect of plant foods may not be restricted to potassium citrate and/or malate (together with some succinate, fumarate) but could also be exerted by poorly absorbable anions (uronates), provided that they are substrates for the large intestine microflora. Whether this observation is also relevant for a fraction of SCFA arising from dietary fibre breakdown (which represents the major organic anions absorbed in the digestive tract in man; Demigné et al. 2004a) is still open to discussion and deserves further investigation through, for example, the use of fibres with different fermentation $\mathrm{pH}$.

\section{Acknowledgements}

Supported by a grant from the APRIFEL (Agence Pour la Recherche et l'Information sur Fruits et Légumes Frais, Paris). The authors also thank S. Mercier, J.-C. Tressol and P. Lebecque for their technical assistance.

\section{References}

Ambuhl PM, Zajicek HK, Wang H, Puttaparthi K \& Levi M (1998) Regulation of renal phosphate transport by acute and chronic metabolic acidosis in the rat. Kidney Int 53, 1288-1298.
Aprikian O, Duclos V, Guyot S, Besson C, Manach C, Bernalier A, Morand C, Rémésy C \& Demigné C (2003) Apple pectin and polyphenol-rich apple concentrate are more effective together than separately on cecal fermentations and plasma lipids in rats. J Nutr 133, $1860-1865$.

Bernalier A, Doré J \& Durand M (1999) Biochemistry of fermentation. In Colonic Microbiota, Nutrition and Health, pp. 37-54 [GR Gibson and MB Roberfroid, editors]. Dordrecht: Kluwer.

Chadwick VS, Vince A, Killingley M \& Wrong OM (1978) The metabolism of tartrate in man and the rat. Clin Sci Mol Med $\mathbf{5 4}$ $273-281$.

Demigné C \& Rémésy C (1985) Stimulation of absorption of volatile fatty acids and minerals in the cecum of rats adapted to a very high fiber diet. $J$ Nutr 115, 53-60.

Demigné C, Sabboh H, Puel C, Rémésy C \& Coxam V (2004a) Organic anions potassium salts in nutrition and metabolism. Nutr Res Rev 17, 249-258.

Demigné C, Sabboh H, Rémésy C \& Meneton P (2004b) Protective effects of high dietary potassium: nutritional and metabolic aspects. J Nutr 134, 2903-2906.

Dongowski G, Lorenz A \& Proll J (2002) The degree of methylation influences the degradation of pectin in the intestinal tract of rats and in vitro. $J$ Nutr 132, 1935-1942.

Fernandes I, Laouari D, Tutt P, Hampson G, Friedlander G \& Silve C (2001) Sulfate homeostasis, NaSi-1 cotransporter, and SAT-1 exchanger expression in chronic renal failure in rats. Kidney Int 59, 210-221.

Finkle P (1933) The fate of tartaric acid in the human body. J Biol Chem 100, 349-355.

Frassetto LA, Todd KM, Morris RC \& Sebastian A (1998) Estimation of net endogenous noncarbonic acid production in humans from diet potassium and protein contents. Am J Clin Nutr 68, 576-583.

He FJ \& McGregor GA (2001) The beneficial effects of potassium. Br Med J 323, 497-501.

Kunzelmann K \& Mall M (2003) Electrolyte transport in the mammalian colon: mechanisms and implications for disease. Physiol Rev 82, 245-289.

Lock K, Pomerleau J, Causer L, Altmann DR \& McKee M (2005) The global burden of disease attribuable to low consumption of fruit and vegetables: implications for the global strategy of diet. Bull World Health Organ 83, 100-108.

Lord RS, Burdette CK \& Bralley JA (2005) Significance of urinary tartaric acid. Clin Chem 51, 672-673.

Marangella M, Di Stefano M, Casalis S, Berutti S, D'Amelio P \& Isaia GC (2004) Effects of potassium citrate supplementation on bone metabolism. Calcif Tissue Int 74, 330-335.

McDonough A, Thompson CB \& Youn JH (2002) Skeletal muscle regulates extracellular potassium. Am J Physiol 282, F967-F974.

Morita T, Kasaoka S, Ohsashi A, Ikai M, Numasaki Y \& Kitiyama S (1998) Resistant proteins alter cecal short-chain fatty acid profiles in rats fed high amylose cornstarch. J Nutr 128, 1156-1164.

Mortensen PB, Holtung K \& Rasmussen HS (1988) Short-chain fatty acid production from mono- and disaccharides in a fecal incubation system: implications for colonic fermentation of dietary fibers in humans. J Nutr 118, 321-325.

Pajor AM (1999) Citrate transport by the kidney and intestine. Semin Nephrol 19, 195-200.

Puttaparthi K, Markovich D, Halaihel N, Wilson P, Zajicek HK, Wang H, Biber J, Murer H, Rogers T \& Levi M (1999) Metabolic acidosis regulates rat renal $\mathrm{Na}-\mathrm{Si}$ cotransport activity. Am J Physiol 276, C1398-C1404.

Rechkemmer G, Ronnau K \& Von Engelhardt W (1988) Fermentation of polysaccharides and absorption of short chain fatty acids in the mammalian hindgut. Comp Biochem Physiol A Mol Integr Physiol 90, 563-568.

Remer T (2000) Influence of diet on acid-base balance. Semin Dial 13, 221-226. 
Rémésy C, Levrat M-A, Gamet L \& Demigné C (1993) Cecal fermentations in rats fed oligosaccharides (inulin) are modulated by dietary calcium level. Am J Physiol 264, G855-G862.

Rémésy C, Demigné C \& Morand C (1995) Metabolism of short-chain fatty acids in the liver. In Physiological and Clinical Aspects of Shortchain Fatty Acids, pp. 171-189 [JH Cummings, JL Rombeau and T Sakata, editors]. Cambridge: Cambridge University Press.

Sabboh H, Horcajada M-N, Coxam V, Tressol J-C, Besson C, Rémésy C \& Demigné C (2005) Effects of potassium salts in rats adapted to an acidogenic high-sulfur amino acid diet. $\mathrm{Br} \mathrm{J}$ Nutr 94, 192-197.

Sellin JH (1999) SCFAs: the enigma of weak electrolyte transport in the colon. News Physiol Sci 14, 58-64.
Spiller GA, Story JA, Furumoto EJ, Chezem JC \& Spiller M (2003) Effects of tartaric acid and dietary fibre from sun-dried raisins on colonic function and the bile acid and volatile fatty acid excretion in healthy adults. Br J Nutr 90, 803-807.

Suzuki M \& Kajuu T (1983) Suppression of hepatic lipogenesis by pectin and galacturonic acid orally-fed at the separate timing from digestion-absorption of nutrients in rats. J Nutr Sci Vitaminol 29, 553-562.

Vidyasagar S, Rajendran VM \& Binder HJ (2004) Three distinct mechanisms of $\mathrm{HCO}_{3}^{-}$secretion in rat distal colon. Am J Physiol Cell Physiol 287, C612-C621.

Young DB \& Ma G (1999) Vascular protective effects of potassium. Semin Nephrol 19, 477-486. 